\title{
SIN AS AN AILMENT OF SOUL AND REPENTANCE AS THE PROCESS OF ITS HEALING. THE PASTORAL CONCEPT OF PENITENTIALS AS A WAY OF DEALING WITH SIN, REPENTANCE, AND FORGIVENESS IN THE INSULAR GHURCH OF THE SIXTH TO THE EIGHTH CENTURIES
}

\author{
WILHELM KURSAWA* \\ University of Nottingham
}

\begin{abstract}
Although the advent of the Kingdom of God in Jesus contains as an intrinsic quality the opportunity for repentance (metanoia) as often as required, the Church of the first five-hundred years shows serious difficulties with the opportunity of conversion after a relapse in sinning after baptism. The Church allowed only one chance of repentance. Requirement for the reconciliation were a public confession and the acceptance of severe penances, especially after committing the mortal sin of apostasy, fornication or murder. As severe as this paenitentia canonica appears, its entire conception especially in the eastern part of the Church, the Oriental Church, is a remedial one: sin represents an ailment of the soul, the one, who received the confession, is called upon to meet the confessing person as a spiritual physician or soul-friend. Penance does not mean punishment, but healing like a salutary remedy. Nevertheless, the lack of privacy led to the unwanted practice of postponing repentance and even baptism on the deathbed. An alternative procedure of repentance arose from the sixth century onwards in the Irish Church as well as the Continental Church under the influence of Irish missionaries and the South-West-British and later the English Church (Insular Church). In treatises about repentance, called penitentials, ecclesiastical authorities of the sixth to the eight centuries wrote down regulations, how to deal with the different capital sins and minor trespasses committed by monks, clerics and laypeople. Church-representatives like Finnian, Columbanus, the anonymous author of the Ambrosianum, Cummean and Theodore developed a new conception of repentance that protected privacy and guaranteed a discrete, an affordable as well as a predictable penance, the paenitentia privata. They not only connected to the therapeutic aspect of repentance in the Oriental Church by adopting basic ideas of Basil of Caesarea and John Cassian, they also established an astonishing network in using their mutual interrelations. Here the earlier penitentials served as source for the later ones. But it is remarkable that the authors in no way appeared as simple copyists, but also as creative revisers, who took regard of the pastoral necessities of the entrusted flock. They appeared as engaged in the goal to improve their ecclesiastical as well as their civil life-circumstances to make it possible that the penitents
\end{abstract}

WILHELM KURSAWA (Dr. Theol. 1995, University of Bonn; PhD 2017, University of Nottingham) is Roman Catholic Parish Priest in Schwalmtal, Germany. Email: wilhelm.kursawa@kkg-schwalmtal.de. 
of the different ecclesiastical estates could perform their conversion and become reconciled in a dignified way. The aim of the authors was to enable the confessors to do the healing dialogue qualitatively in a high standard; quantity was not their goal. The penitents should feel themselves healed, not punished.

KEY WORDS: Ambrosianum, Basil, Cassian, Columbanus, confessor, Cummean, Finnian, Insular Church, Oriental Church, paenitentia canonica, paenitentia privata, remedial character of penance, penitent, penitential literature, sixth-eighth centuries, sin as an ailment of the soul, soul-friend, confessor as a spiritual physician

\section{Theological Preamble}

The advent of the Kingdom of God in Jesus, personally, contains as an intrinsic quality the opportunity for conversion and reconciliation as often as required (Matthew 18: 20-21), because in the sight of Jesus repentance (metanoia) is an on-going process of life. So it is astonishing that a serious problem with the case of repeated sinning and the chance of following reconciliation appeared in the developing community of Jesus-followers, in the growing church. The dynamics of the beginning laid the focus on forming a community living a holy and exemplary life. Being a 'new creation in Christ' (2 Corinthians 5: 17) and the christened person is called to be 'dead to sin but alive for God in Christ Jesus' (Romans 6:11) the view on the converted person appeared as markedly optimistic. Thus, the baptism initially represented the only way for the forgiveness of a sinful life. But the experience that performance of a faultless life even after the divine gift of baptism demanded too much of the faithful, eventually led to the undesirable development that people postponed their baptism to the last moment of life, onto the deathbed. Therefore, from the beginning of the church onwards an urgent demand can be perceived for the opportunity of repentance.

Taking up this demand especially for capital, later called 'mortal' sins (apostasy, murder and fornication), the development of the Christian congregation conceded a second chance to be reconciled with God and the community. But its conviction to maintain the exemplary nature led to the church's practice that the chance of repentance has to be limited to a single opportunity. This alleged solution however proved itself a disappointing choice, because human nature remained tempted and a relapse into sin more frequently than once happened in a human being's life-time. In addition to this problem confession of the fault as well as the imposition of penance occurred publicly in front of the congregation (exomologesis, in Tertullian 1869: 9, 1). Not only that the transgressor was blamed for his or her transgression the penance especially turned out extremely harsh. Basil of Caesarea developed a four-step-system of repenting: being a no longer a full member of the celebrating congregation the penitent after committing the capital sin of murder for example had to endure a twenty-years penance: four years as a weeping person outside the church, another five years 
listening to the liturgy of the word, seven years kneeling during the divine service and after serving four more years standing in the church he or she was reconciled and allowed to received the communion (Basil 1839: 472). But alongside with the hard conditions of penance especially the Oriental Church, meaning the 'Greek East', developed two important lines of further dealing with sin, repentance and forgiveness:

1. Sin was seen as an ailment of the soul. Thus the penance had the character of a remedy. Healing, not punishment was in the foreground. Using the metaphor of physicians of the body the physicians of the souls are called to use appropriate medicine to cure the ill soul.

2. The model for these doctors of soul is Christ. He not only is one physician among other doctors, as the redeemer he is the 'principal consultant', who can heal the wounds of sin. So the confessors, the spiritual physicians have to assist Christ in the pastoral care for the sinner by an engaged spiritual guidance. This guide on the one hand is called on to help people in recognizing temptation and how to overcome it. On the other hand, he encourages the sinner to repent and fulfill the penance until he or she becomes reconciled with God and the church. The spiritual guide is called to make the penitent's burden of his own. In this way, he acts like an anmchara, a soul-friend, who is mentioned in the later Insular Penitentials.

The act of repentance, meaning the reception of confession, the imposition of penance as well as the rite of reconciliation, was normally reserved to the bishop. This regulated, as it were 'canonized', procedure developed itself as the ordinary way of repentance in the third and the next centuries and therefore is defined as canonical penance (or canonical repentance). But this procedure too did not resolve the problems of repentance. On the contrary: because the moment of dying abbreviated all periods of penance the procedure of repentance also became increasingly postponed to old age or even to the hour of death. So an urgent request of a different way of repentance was coming up, indicated along the following lines: not solitary, but repeatable, not public, but confidential and with regard to penance not dependent on the confessor's discretion, but following common and calculable regulations. Indeed, a new practice of repentance appeared in the sixth century at the Western edge of the Christian World: in particular authorities of the Irish Church or areas of its influence on the Continent and in England (hereinafter: Insular Church) developed a way of repentance which protects privacy and guarantees an affordable as well as a predictable penance: the paenitentia (poenitentia) privata, conceptualized in the Penitentials.

\section{The Significance of the Penitentials}

These Penitentials appear in a first sight as a catalogue of fines and seem to represent a list of capital sins as well as minute trespasses, which corre- 
sponds to a classified enumeration of related penitential works. Catalogues and handouts easily come under the suspicion as tending to superficiality, because they are generally designed for mass use and distribution. To prove that this light-minded rating by no means meets the actual value of the Penitentials for the historic and pastoral development of the church in the insular world and the continental of its influence needs a detailed scrutiny. This applies particularly to the basic penitence-writings of the sixth to the early eighth century. At a time when word-of-mouth, face to face talks or letters were the sole means of communication a surprisingly well working network can be detected in the writings of this genre. The selection of these penitence-writings in this essay is neither casual nor unplanned. It will become apparent that the selected Penitentials are basic ones. Mutual influences are evidently, they partly built on each other, complete the content and form a pattern for later writings from the eighth century onwards. They also represent ecclesiastical documents, which-dealing with partially rough human behaviour and attitudes-provide revealing glimpses into the life of the developing Church and its relations with an often unruly and violent civil society at a time when secular documentation is scant.

\section{The Writings and Their Origin}

The modalities of this alteration turned up in the different writings about repentance in the sixth, the seventh and the eighth century compiled by British and Irish authors, who acted as collectors, compilers and revisers. Some of these ecclesiastical figures are known and identified as authors: unequivocal Patricius (fifth century, O'Loughlin 1999) and Columbanus (seventh century, Walker 1997), with some probability Vinnianus (of Clonard, sixth century, Bieler 1975) and Cummeanus (seventh century, Bieler 1975 and McNeill and Gamer 1979). The name of others is attached to certain issues, but their authorship is questionable: Gildas and David of Menevia (sixth century, Bieler 1975 and McNeill and Gamer 1979). Two more appear as decisions of local synods of far reaching influence: Sinodus Aquilonalis and Sinodus Luci Victoriae (sixth century, Bieler 1975 and McNeill and Gamer 1979). The author of Paenitentiale Ambrosianum (seventh century, Körntgen 1993) remains anonymous. But good arguments can be made that he was an Irish ecclesiastical in the environment of Columbanus on the Continent.

A cluster of writings eventually represents records of the late seventh and early eighth century (Discipulus Umbrensium) taken from the advice of the important authority Theodorus, the former Greek monk and archbishop of Canterbury (Finsterwalder 1929). But no original writing or writtenreport of these authorities has survived. The extant documents represent manuscripts mainly copied from the eighth to the twelfth century in the 
scriptoria of continental monasteries. So it is not surprising that not only the named authorities can be counted among the authors, who were responsible for the texts. Disciples and followers later took over, but also revised the rules to adapt them to a changing target group, political and social environment, necessary pastoral request and different ecclesiastical areas. Therefore, all these documents possess a file character and allow an insight into the altering ecclesiastical, but also civil circumstances and conditions. Each of the selected writings simultaneously represents in its own way a pattern for further penitence-writings from the eighth century onwards. In the course of time the statements give evidence of an ever-increasing networking and reveal the observation that quite often the later writers used the earlier writings as source.

\section{Severity of Trespasses and Scheme of Vices}

Three general classes of trespasses (spiritalia vulnera, vitia: P. Ambrosianum, delicta: P. Cummeani, cicatrix: D. Umbrensium) according to their severity (iuxta magnitudinem culparum: P. Columbani) appear in the different penitencewritings: capital (peccata capitalia: Excerpta Davidis, crimina capitalia respectively peccata praevalenta: P. Columbani, mala, lapsus: D. Umbrensium) or (later called) mortal sins (peccatum ad mortem: P. Ambrosianum), grave sins (scandalum, magnum crimen: P. Vinniani), and minor sins (peccatum parvum: P. Ambrosianum, minutae causae: P. Cummeani). Although the multitude of terms to describe the severity of sins shows that the boundaries are often fluent, the networking relations run like a common thread through all the Penitentials. It requires some effort to unravel these tangled threads of cross- and interconnections, but exactly this examination reveals the astonishing network.

The contribution of the bridge-building authority John Cassian (c. 360432) to the development of the concept of repentance in the Insular Church is important and cannot be overestimated. This becomes particularly obvious in the Penitentials by many examples of networking in adoption of John Cassian's Eight-Vices-Scheme: Columbanus learnt about the eightfold scheme of vices during his life-time in Gaul. His small tract: De octo vitiis principalibus, appears as one of the first, if not the first mention of Cassian's vice-catalogue by an author, who comes from and keeps up connections to the Irish Church. These Irish roots as well as his sojourn on the continent the author of the $P$. Ambrosianum had in common with Columbanus.

Within his environment, the Ambrosianum's author came across with Cassian's Eight-Vices-Scheme and introduced it as a systematizing element into his penitential probably during the first ten years of the seventh century. He eventually transferred it back by this bridge-building-text into Ireland, where the P. Ambrosianum was acquired as the main source of the Paenitentiale Cummeani, written around 650. According to the testimony of the Dis- 
cipulus Umbrensium this Irish penitential (ex Scottorum libellus) became a pattern for the P. Theodori. The Discipulus however used it partially and structured only the first three canones according to Cassian's Eight-Vices-Scheme.

The Northumbrian Disciple developed for his issue of $P$. Theodori an individual that is a combined system: precisely defining the trespass as well as identifying the group of trespasser and their ecclesiastical estate. Despite this individualistic adaptation, the consistent entire relations can be proved by the programmatic introduction of the P. Ambrosianum: the author followed John Cassian and described gluttony (gula) as a basic reason for all other vices (radix multifarium vitiorum). This interpretation consequently appears at the beginning of the Excerpta Davidis (gulae gratia), canon I of the $P$. Ambrosianum (De ebrietate), Cummeani (De gula) and Theodori (UI 1: De crapula et ebrietate).

\section{'Coarbial' Coexistence of Monastic and Outer-Monastic Domain}

All writings have in common the trias of capital (mortal) sins: apostasy, murder, and fornication. It is striking that trespasses against chastity (fornicatio) in its variety of manifestations appear as a severe problem in the inner- as well as the outer-monastic area. The Sinodus Aquilonalis, the Praefatio Gildae (and Columbanus' Regula coenobialis respectively part A of his Penitential) focus on the upkeep of discipline and morale among the monastic family (Irish: manaigh), which consists of three classes of membership: coenobitics, learnt monks of the entire community, brethren, lay-monks working in the monastery's agriculture or craft workshops, all living within the walled enclosure. As a third class tenants of monastic land belong to monastic family dwelling outside the wall with their families. They all were under the care and the rule of the monastery's abbot. So the area of the abbatial influence was not only restricted to monks within the enclosure, but also was extended to clients outside the monastery.

This extension across the monastery's walls required a wider range of care by the abbot and his community. It necessitated among others the development of a pastoral of repentance. An exile into another monastery or ecclesiastical area for example was certainly possible for a monk, but much more difficult for clerics and definitely almost impossible for lay-people outside the monastery. Or blows as a form of penance would have been more accepted in a closed congregation of monks than in a civil society. On the other hand, the world outside the monastery provided other methods of penance, which appeared as impossible within a monastic community: pecuniary compensation, restitution of goods, almsgiving, selling or setting free bondservants, ban from marital intercourse or carrying arms. All these circumstances and consequences marked the transition of regulations for repentance from inside a monastery into an outside civil society. Therefore, 
it represented the actual manifestation of a pastoral of repentance as it appeared in the $P$. Vinniani and the later Penitentials. This situation additionally created an uncertainty about the borderline between the jurisdiction of the monastic settlement and the diocese of this area.

The key-word of this problem's solution is 'coarbial' (Davies 2005: 143, 144). This meant exactly a coexistent ecclesiastical organization, which was ruled by a lay-element as well as a hierarchical one: local leading families, often playing the role as benefactors, on the one hand and bishops and abbots on the other. Regarding the pastoral care, 'coarbiality' in particular meant a kind of negotiated co-existence of abbatial and episcopal authority: depending on local circumstances an abbot could act as a principal of a monastic settlement as well as bishop of a certain ecclesiastical province. Or a bishop as the head of a diocese also could possess the function of an abbot.

In addition a 'coarbial' relationship between an abbot and a bishop existed in its entire sense in form of cooperation with clearly and unambiguously competences and responsibilities (Liber secundus of the Discipulus Umbrensium). Traces of this mutual toleration of pastoral care concerning repentance to the circle of diocesan clergy and lay-people as well as possible conflicts between local bishops and abbots already can be found in the Praefatio Gildae, a writing which actually referred to a monastic area: a sinning presbyter or a deacon, who did not take vows, has to be treated like a monk before his solemn promise. And a monk-priest should not be prevented from praying for his bishop (Praefatio Gildae, P. Cummeani).

Consequently, the matter of capital (mortal) sins had to be extended to serious trespasses, which primarily occur in a society outside a monastery: apostasy, homicide and adultery as a special form of fornication. The penitence-writings in their entirety are consistent with the regulations that apostasy, fornication and homicide belong to the mortal sins. Here the upkeep of discipline and morale within the monastery corresponded alongside with an inner-church disciplining to a legal civilization of the society as a whole. In the Oriental Church, emperor Iustinianus I (482-565) crowned an effective legal system within all the regions of the East-Roman-Empire by the Codex Iustinianus (529). But in contrast, the English and Irish provinces of the Church (Insular Church) lacked a proper civil authority able to maintain law and order after withdrawal of the Roman legions in 410 .

Addressing this problem in the fifth and the following centuries ecclesiastical authorities tried to fill that gap of civil insecurity simultaneously with the organisation of a regulated ecclesiastical life. In internal insecure circumstances in the fifth century, for example, Patrick (Epistola ad milites Corotici) wanted to use his authority as bishop to protect his entrusted flock in Ireland from Coroticus' raid and abduction into slavery. In this context, Patrick condemns all collaboration with those raiders, especially for the sake of 
profit. A similar effort to avoid an external situation of insecurity during the Anglo-Saxon invasion into England in the sixth century appears in the $S$. Luci Victoriae's threat of drastic penance for guiding heathen barbarians to Christian settlements.

The handling of this treason reveals another instructive random sample of networking: its mention in the Irish P. Cummeani (canon IX) is obviously taken from the decision of the British S. Luci Victoriae, a hundred years earlier. The evidence of networking appears in an almost similar description of the wrong-doing and the following consequences: no bloodshed, thirteen or fourteen years of penance and a lifelong ban from carrying arms. In the case of bloodshed however a lifelong penance by living like a monk was given. But this cross-reference also shows that the importance and topicality depended on the circumstances of time and place: Cummean's classification under the headline De minutis causis namely indicates that almost a hundred years later this incidence did not represent a commonly occurring and pressing problem. In any case, it must have been in Cummean's vivid memory that this problem still existed in Ireland in Finnian's time: in his Paenitentialis the trespass of embezzling money for ransoms point to the necessity to pay for the liberation of captives, a regulation that is repeated almost literally in P. Cummeani.

Furthermore, the order to compensate the affected of offences against the corporal integrity or to restore stolen property (P. Vinniani, Ambrosianum, Cummeani) reveals the comprehensive understanding of pastoral care: healing of spiritual and corporal wounds of the offender (penance as remedy) and victim as well as relief of social iniquity for the wronged party. The same applies to the prescription to pay for the medical expenses after an injury of a person (P. Cummeani). This might be the reason, why in the $E x$ cerpta Davidis as well as in the P. Ambrosianum fraud (dolus) is enumerated alongside with the capital sins of homicide (homicidium) and fornication (fornicatio). The $P$. Vinniani counts perjury (iurare iuramentum falsum) among the magna crimina, possibly in Finnian's sight a capital sin as well.

\section{Consequences of Disbelief and Its Practice}

The regulations concerning erroneous ways in Christian belief and its practice can serve as a good example for the conformities as well as the diversities depending on local- and time-conditioned problems. Under the keyword apostasy three manifestations of disbelief or related actions can be noticed: raid on Christians by barbarized fellow-believers or guidance of heathen invaders to Christian settlements for profit (Epistola ad milites Corotici, $S$. Luci Victoriae and P. Cummeani); the practice of magic, superstitious ceremonies, and relapse into paganism (P. Vinniani, Columbani, Theodori); finally 
propagation and acceptance of heresies (P. Columbani in connection with his Epistola $V$ and Instructio I, P. Ambrosianum, and Theodori).

Superstition and the use of magic actually appear primarily in Irish Church and represents there a serious offence (P. Vinniani: immane peccatum) against the integrity of the Christian faith. Superstitious practice marks a situation of transition from a pagan to a Christian society. This might explain why alongside with lay-people clerics had been enmeshed in those actions. Being rated as replacement of the druids the ordinary people in particular requested from the ecclesiastical officials assist one in coping with hardships of life and nature as well as personal needs. Even if this offence against the Christian belief was not in the foreground of the P. Columbani and the P. Theodori (UI XV), it can be observed that both Penitentials contain similar or comparable regulations. This is not surprising because of their close connections to the Irish Church. These forbidden activities include offences effecting personal harm (worst case: abortion), but also actions like application of love-philter, incantations, auspices, and oneiromancy. Especially Theodore's penitential draws a line from the ancient Oriental Church and revisits the tradition from Basil's advice in his Canonical Letter 217.

The crucial point on the Continent (without neglecting superstitious misuse) was the meeting with erroneous theological concepts and the preferential necessity to ward them off (P. Columbani, Ambrosianum, and Theodori). Although the Ambrosianum does not address a special heresy, the context makes clear that the regulations deal with error about fundamental questions of the Christian doctrine. The associated problems are unequivocally of theological matter. The Ambrosianum has this concentration on fundamental theological discussion in common with the P. Columbani and Theodori. Precisely heresy is the topic, which Columbanus focuses on in his Penitential when he points to Bonosiacs, who supported an aberrant thesis in Christology. Here Theodorus followed Columbanus and the Ambrosianum's author. But Theodore went far beyond this: the $P$. Theodori, especially the issue compiled by the Discipulus Umbrensium, proves itself as a kind of summary of the preceding penitence-writings. So the Theodorian directions deal with a comprehensive list of disbelief in the insular and continental church of the sixth to the eighth century: heterodoxies in the narrow sense like the Pelagianism, Arianism and the Bonosiacs; the Quartodecimans, followers of the Irish deviation of determining the Easter-date, a trespass against the Church's discipline, which Columbanus defended in his Epistula I; in tradition with Basil (Epistula 217) leaving the church not forced by violence; worshipping idols (in common with Columbanus) and committing various practices of superstition and magic (in common with Vinnianus). 


\section{Corporal Assault: Example for the Relation of Intention and Execution}

Another basic pastoral condition of dealing with capital, grave and minor sins exist in the Penitential's advice to take note of the penitent's personal abilities and the circumstances of their wrongdoing. The pastoral concept of the Penitentials is profound: not only the execution, but already the intention to commit and the plan to carry out a trespass appear as enforced by penance. The examples are countless and culminate in the Scripture's quotation that the one, who hates his brother, is like a murderer (P. Vinniani, Ambrosianum, Cummeani). Phrases to describe an intention and a plan like peccatum voluere (P. Gildae) or per cogitationem peccavere (P. Vinniani, Columbani) point to a distinction and a climax of personal guilt and attached penance, which runs like a thread through all penitence-writings (P. Ambrosianum, Columbani, Cummeani, Theodori) since the Excerpta Davidis: trespassing caused by ignorance (per ignorantiam), superficial negligence (per negligentiam) and intention (per contemptum). The $P$. Vinniani uses a comparable differentiation to distinguish between murder, manslaughter and mayhem: ex odio (hate) meaning intentional homicide (murder). The unplanned or non-intentional homicide (manslaughter or mayhem), non ex odio, arises from the various forms of anger (rage, fury).

This is the reason, why the Penitentials, which are structured according to John Cassian's Eight-Vices-Scheme (P. Ambrosianum and Cummeani), listed homicide under the headline 'ira'. The distinction between the different corporal attacks has tradition: in his Epistola 188 Basil distinguished assaults against corporal integrity in voluntarius and involuntarius. John Cassian adopts in his Collationes (fifth conference with the abbot Serapion) from the Pastor of Hermas the three steps of escalating of annoyance: anger (thymos) can grow via rage $(\operatorname{org} \bar{e})$ into lasting fury (mennis). The two related groups of distinguishing feature are in parallel use and repeated in the P. Ambrosianum, Cummeani and Theodori. Other reasons to lessen the burden of penance are infirmity (Excerpta Davidis) and younger age (Sinodus Aquilonalis, $P$. Cummeani).

\section{Trespasses against Chastity}

Under the collective term fornication (fornicatio) all Penitentials deal with the whole spectrum of sins against chastity. This appears as evident, if the latest of the examined Penitentials, Archbishop Theodore's Penitential in the compilation of the Discipulus Umbrensium, is due to its collective character considered a summary of all preceding penitence-writings: almost a third of the decrees in this Theodorian issue contain regulations about the degree of penance when a person commits a trespass against chastity. The transgressions reach from minor trespasses like forbidden familiar touches or lascivious embraces to capital sins like immoral sexual activities: illegitimate inter- 
course, incest, homosexual practices (sodomy) and sexual actions with animals. The description of these indecent acts were of a disarming candour, a detailed frankness, which sometimes led to the curious advice to the confessor not to wise up the penitent about potential sins in all its particulars (Theodulf 1851: 219).

The comparison of the two West-British penitence-writings, the Praefatio Gildae and the Sinodus Aquilonalis, with the later Sinodus Luci Victoriae clearly marks the transition from inner-monastic regulations to an ambit outside a monastery: the S. Luci Victoriae explicitly addresses a fornicator as an adulterer, a sin, which can be committed only among married couples. The integrity of the bonds of wedlock already had been defended in the P. Vinniani: neither barrenness nor adultery justifies a partner to abandon the marital bond and enter into a new marriage. Finnian conveys the insight that the circle of clerics was obliged to a chaste form of life: a married man, whose wife is still alive, actually could be ordained deacon. But although his wife remained in his care, being further on his clientella, he has to live with her in chastity, like a puella aliena. The Penitentials also show that the ecclesiastical authorities continued to interdict extramarital relationships and tried to forbid any form of concubinage. This upkeep of public morale went along with an upgrading of an ancilla's status: from a woman without rights (slave) to a person (bonds-maid), who could demand basic legal entitlements, at best to be released in case of begetting a child from her master $(P$. Vinniani, Cummeani).

\section{Other Trespasses}

The penance on trespasses against reliability and honesty as well as property offences (raid, theft, fraud, overreaching, usury, lies, and perjury) depended on their seriousness and varied from fasting to excommunication. Alongside with the imposition of penance the Penitentials' regulations emphasized the unconditional demand of compensation. With reference to the Scripture, it appears as a running thread in the Penitentials that the wronged party could claim a generous restitution of robbed cattle or stolen property, often clearly demanded fourfold. Intransigence and refusal of compensation entailed serious consequences and carried the penance of exclusion from the ecclesiastical community. So the Penitentials again turned out as guidelines to maintain harmony within the church, simultaneously to pacify civil affairs and help to create an intact society. Keeping these societies in good health the Penitentials provided a series of hygiene rules: interdiction to devour carrion, prescription to touch food with clean hands, disposal of spoiled foodstuff or food contaminated by dead mice or weasels. 
All the Penitentials' directions showed an enormous effort to foster religious life and practice among the faithful. Liturgy and pastoral care had to be performed in a proper and reverential way. In this context, the awe of the sacrificium, meaning the consecrated host and wine, took up a dominant position and is reflected in numerous and detailed prescriptions (Praefatio Gildae, P. Vinniani), often added in a separate canon (Regula Coenobialis, P. Ambrosianum, Cummeani, Theodori [Discipulus Umbrensium]). These prescriptions actually draw a realistic picture of the particular ecclesiastical life and reveal a precise knowledge of ordinary liturgical and pastoral activities as well as their requirements, challenges and problems: proper education of the officiating ministers to pronounce the liturgical texts accurately and intelligibly; sobriety and temperance of ecclesiastical officials to avoid slurring during divine service or even vomiting the consecrated host; good practice in suitable storing and careful transporting of the sacrificium and experience of dignified handling in case of losing the consecrated species; clerical conscientiousness and engagement in ministering the flock, taking care of the housebound and ensuring children are baptized.

\section{A Tool to Define More Closely Time and Place of a Penitential's Origin}

As a historical side effect the detailed examination of the Penitentials' rules can provide valuable indications about time and place of origin of writings, whose formation and authors appear as obscure and anonymous.

\section{Chronological Classification of the 'S. Aquilonalis' and 'S. Luci Victoriae'}

Manslaughter, collaboration with invaders (because of greed for profit), adultery, and perjury as they appear in the decrees of the Sinodus Luci Victoriae are typical faults of a civil and not a monastic community. If the Sinodus Aquilonalis restricts itself exclusively on regulations for a monastery and the Sinodus Luci Victoriae extends regulations for penance onto non-religious people, so a high probability exists for the following interdependence: the synod, which was setting up rules only for monks, had been followed in time by the ecclesiastical meeting for a greater group of Christians, meaning for those, who live inside as well as outside a monastery. So the conclusion can be made that the Synod Luci Victoriae assumes the knowledge of penances of the Sinodus Aquilonalis. This synod therefore took place first followed by the Sinodus Luci Victoriae.

\section{Chronological and Geographical Classification of the 'P. Ambrosianum'}

Another good example for the chronological as well as the geographical classification arises from the comparison between the Columbanus' Regula coenobialis and the P. Ambrosianum. The Ambrosianum and Regula coenobialis mention the care to provide house bound faithful with the sacrificium. In context with this pastoral service both writings describe the same landscape 
and infrastructure: navigable lakes or rivers, bridges to cross the waterways and roads sufficient to ride on by horse. Therefore, it could happen that the container (pyxis) with the consecrated host accidently fell into the water while rowing in a barge on a lake or river. The $R$. Coenobialis and the P. Ambrosianum have in common the variant spelling of the Latin word for barge: cimba. This sequence of letter however represents a misspelling of the original Latin term cymba (a calque from the Greek word kymbe) or cumba. The mutual use of cimba however points to a close relation of these two sources in time and place. Considering other striking similarities this essay proposes the thesis that the Paenitentiale Ambrosianum was composed on the continent in the close environment of Columbanus and his followers sometime around the first decade of the seventh century.

\section{Chronological classification of the different issues of the 'P. Theodori'}

Another detailed examination, using the degree of systematizing, leads to a temporal classification of the different issues in the $P$. Theodori: the finding of the relatively unstructured organization of D (Iudicia Theodori) in comparison with the other issues corresponds meaningfully with the statement that D itself comes out as an early copy of one of the earliest records echoing the Archbishop Theodore's directions. So it does not go without notice that there an upward tendency in systematising the material can be found: from a rather low structured D upward G (Canones Sancti Gregorii Papae) with an approach of summing up to the partly headlined Co (Iudicium de paenitentia Theodori) and finally to the clearly and systematically structured U (Discipulus Umbrensium) written down in the second decade after Theodore's passing away, before the middle of the eighth century.

\section{Character of Penance}

The Praefatio Gildae contains the advice that a brother, who suffers from an offence of another member of the community, is asked to inform the abbot in a conciliating manner, in the spirit of a physician (medentis affectu). This however is the only reference to a therapeutic meaning of penance. It appears as likely that this direction represents a kind of delineation to distinguish between necessary information to the monastery's principal and unnecessary disputes of the brethren about marginal problems: if these permanent mutual accusations disturbed the community's harmony, the Sinodus Aquilonalis regulated that the accused (dilatus) brother had to be treated like the one, who is the accuser (dilator). This regulation later was repeated in the P. Ambrosianum and Cummeani, obviously in the context of monastic life. This example of two benchmarking regulations suggests the assumption that the upkeep of discipline within the community is to the fore of the four South-West British penitence-writings. The punishment of strokes 
achieves another support for this notion: this special form of penance is quoted mainly in Columbanus' Regula Coenobialis, infrequently scattered in the P. Ambrosianum and Cummeani and mentioned always in a monastic context. So the conclusion appears as likely that the authors of the four SouthWest-Britain directions of penance had no detailed knowledge of the concept of the ancient Oriental Church: penance as remedy for sin as an ailment of the soul.

But the earliest extant Irish penitential, the $P$. Vinniani, changed the perspective on sin and repentance, and developed an entire pastoral viewpoint: Finnian did not downplay the personal guilt, not at all, but he provided a way out. By the adoption of the ancient Oriental Church's concept he laid the focus on sin as an ailment of soul, repentance as a process of healing, penance as the related medicine and the priest (sacerdos) as a spiritual physician. Being tantamount to the soul-friend (anmchara) this conception of reconciliation attached great importance on a personal relationship between confessor and penitent. All further Penitentials followed this concept. This comprehensive process of physical, mental and spiritual healing becomes particularly clear in the way the Ambrosianum's author dealt with the fifth vice of dejection (tristitia): he expects melancholy persons to activate their self-healing forces and allots to the priest the role to support their effort. Finnian indeed reveals the knowledge of an important rule of ancient medicine and shifted it into a suitable remedy for a trespasser's cure: contrariis contraria curare. Therefore, he recommended meeting vices (wrath, envy, backbiting, gloom, greed) by virtues (patience, kindness, discretion, joy, generosity). While he mentions only an incomplete list of John Cassian's catalogue of vices (and related antidotes), Columbanus obviously had available a more detailed knowledge of Cassian's system of misbehaviour (and its counteragents).

In his small tract, De Octo Vitiis Principalibus, he delivered Cassian's complete Eight-Vices-Scheme. As a result of a detailed examination of the relevant documents this study proposes that the author of the Ambrosianum, which is found in the ecclesiastical environment of Columbanus on the Continent, took over Cassian's scheme as an element to structure his penitential. The $P$. Ambrosianum represents the main source of the Irish $P$. Cummeani. So it is likely that the $P$. Ambrosianum took the role of a bridge-function: Cummean and partly the Discipulus Umbresium later used Cassian's Eight-VicesScheme to systematise their penitentials. The Irish penitentials in particular underline the outstanding relevance of John Cassian, who imparted in the fourth and fifth century the monastic movement of the Kellia (the desert of Upper Egypt), its spirituality and discipline into the Continental and Insular Church. 
In his epilogue, Finnian again underlined that penance represents a remedy for proceedings, which need to be cured. The therapeutic character of the prescriptions henceforward represented a consistent element of all further penitentials. Columbanus seizes the idea of the Christos-Iatros-motif. In his Instructio XIII, 3 (Walker 1979: 120) he called Jesus Christ as the salutary physician. Columbanus' Penitential regulated, that in the Lord's succession the spiritual physicians were ordered to apply a therapy for the wounds of souls. As the doctors of the body use an appropriate treatment for the varying diseases the physicians of the soul carefully have to choose nuanced penance as remedy for the illnesses of the soul, meaning the sins and trespasses of different severity. This particular prescription to establish a suitable selection of remedies related to a system of illnesses appeared as a crucial element in the introduction of the P. Ambrosianum.

The author of this penitential is convinced that all evil behaviour develops itself from the basic vice of gluttony. This sin, which represents Cassian's gastrimargia (the victory of the stomach over the spirit), can be cured by the medicine of an adequate penance. In his prologue, Cummean too described penance as medicine for a soul's cure. Prior to the prescriptions of his penitential, wherein he followed Cassian's Eight-Vices-Scheme and the traditional rule to heal contraries by contraries, Cummean supplemented this catalogue by a list of twelve salubrious works. These good actions effect remission and support the penance, which is imposed by the different regulations of the penitential. This recital again shows the astonishing relations and the penitential's place in the network of the history of repentance. Cummean's hint to the Fathers reveals its source: the twentieth conference with the abbot Pinusius in Cassian's Collationes (2004: 561-563). But this is not the immediate reference. The different enumeration of passio martyrii (number twelve instead of Cassian's number two) points to Caesarius of Arles (470/471-542) as Cummean's source: the martyr's passion also is the last on the list in Caesarius' (1865: 1075). The Discipulus Umbrensium finally mentioned explicitly in his preface the remedium paenitentiae and dedicated his edition of Theodore of Canterbury's advice programmatically to 'all the catholic physicians of souls of the English'.

The Irish authority Finnian also emphasizes for the first time the boundless magnitude of God's mercy: there are no temporal limits, no limitations with regard to the contents for the forgiveness of sins, and strictly in privacy. This represents the explicit breakthrough for an unlimited opportunity to repent and receive forgiveness of sins after serving the imposed penance. The following Penitentials affiliate to this notion, except the $P$. Theodori. This exception is mentioned in the issue of the Discipulus Umbrensium: in the provinces of the church under Roman or Greek influence the penitents were reconciled publicly on Holy Thursday by the bishop or an authorized 
priest. In the province north of the Humber, however, influenced by the Irish Church the reconciliation took place in privacy, reasoned by the fact that a public repentance in this province did not exist.

This finding clarifies two important conclusions: firstly, the transition from procedures of public repentance (paenitentia canonica: in the church and executed by a bishop) to a secret confession and imposition of penance (paenitentia privata: performed by a priest) represented a long-lasting process. Its appearance depended on certain ecclesiastical areas and still was on its way around $800 \mathrm{AD}$.

Secondly, the private penance actually was developed in the church of Ireland or those provinces, which had been under Irish influence. It is remarkable that, on the one hand, the 'Roman' Easter-date and the form of tonsure got the edge on the Irish custom, but, on the other hand, the Irish influenced performance of repentance, practiced in privacy, eventually proved itself as the prevailing form for the church to come. In details it was recommended even by the Greek monk and English archbishop Theodore.

In this context, the observation is enlightened that the Easter-date and the form of tonsure had been a question of an all-ecclesiastical doctrine and a binding decision of the church. But the Penitentials though their use was widely held until the tenth century never became an official doctrine in the church. The regulation of the Easter-date and the tonsure was supported by the authority of church and its hierarchy. Behind the Penitentials stood talented and acknowledged authorities representing certain areas of the Church.

From this perspective, all the penitence-writings can be seen as a composition work containing a spiritual-forensic pathology of sin and its related spiritual-therapeutic cure. This therapeutic concept of repentance can be read as a pastoral effective way of dealing with overcoming human weakness and encouraging reconciliation after relapse into sin. So the Penitentials mean much more than a catalogue of spiritless and legalistic automatism of penance. Even in the case that such a mechanistic use occasionally appeared later the named authors cannot be held responsible for this incompetent handling of the Penitentials. The author's aim is clear and consistent: they shaped their Penitentials into a crucial assistance in the life-long course of a Christian's life, experiencing the controversies of a human being: success and failure, strength and weakness, holiness and sinfulness.

The pastoral intention of the Penitentials is obvious, because their regulations consistently tried to take into account the socio-personal circumstances of the penitent. This is exemplarily taken all together in the P. Cummeani: the priest is requested to take note of the penitent's personal abilities and the circumstances of his wrongdoing. The confessor is ordered to ponder on the individual sin and penance of the trespasser. Cummean express- 
es his opinion that a priest is acting in an exemplary manner, if he befriends the sinning person and converts the sinner through all his pastoral abilities and spiritual activities (admonendo, hortando, docendo, instruendo, Bieler 1975: 134). So the role of the priests primarily is not to be a judge or an executor of penance, rather the sympathetic and sensible companion, spiritual physician, soul-friend, anmchara of the repentant person. The Penitentials quoted numerous reasons to mitigate the penance: for example, heavy physical work, low education level, ignorance or inadvertence, infirmity, poverty, young or old age and coercion. This careful mention of all these exceptions and special cases support the notion that the penitentials provide entire pastoral activities and a sophisticated matter of cure, by no means a catalogue of automated punishing.

\section{The Minister of Repentance}

On repenting matters, Patrick had already sent an authorized priest (presbyter) to persuade the warlord Coroticus to release abducted fellow-Christians. It represents an early example of delegation of authority from a bishop onto a priest. Among the monastic family, the abbot held the power to rule, of course also in affairs of repentance (Praefatio Gildae). But the decrees of the Sinodus Aquilonalis revealed the institution of a monastic instructor (doctor privatus), who is commissioned to accompany a monk also in the performance of serving his penance. The Excerpta Davidis made the subtle difference between a priest, who ministers in the church (sacerdos) and the general ecclesiastical state of a priest (presbyter).

In the $P$. Vinniani, priests who were ministering the daily ecclesiastical life of the faithful are termed sacerdotes. This is illustrated with the example of those, who administer the fruits of repentance (fructus penitentiae), meaning the distribution of alms received from the penitents. Ordained persons, who had committed a sin, in Finnian's penitential were summed under the term of their estate: clerics (clerici). In the P. Columbani the penitents are entrusted to a bishop or a priest (sacerdos). By the example of dealing with heathen practices from the past Columbanus' Penitential reveals that the priest (sacerdos) too was the one, who accompanies, teaches and guides the ordinary people.

A particularly extensive portrayal of sacerdotal office appears in the $P$. Ambrosianum: the priest (sacerdos [catholicus]) was authorised to receive the confession, to measure and impose the degree of penance, to pray for the penitent and to absolve the repentant. The absolution obviously took place in a liturgy of reconciliation, which was hallmarked by a combination of prayer and affirmation of the forgiveness by the priest. The performance of this reconciling liturgy obviously had been in the competence of the officiating priest: no penitential delivers an official formula of absolution. Cum- 
mean specifies a priest's (sacerdos) ministry expressively in only few canons of his Penitential. This absence of a consistent detailed description of a priest's office and authority in context with confession is neither accidental nor indefinite. It supports on the contrary the conclusion that the sacerdotal ministry already was well known in Cummean's time and therefore did not need any particular mention.

In the ambit of the English Archbishop Theodore two notions of dealing with repentance encountered each other: the Roman respectively the Oriental way (south of the river Humber) and the Irish one (Northumbria). The competence to minister the reconciliation of a penitent was clearly described by the Discipulus Umbrensium. In the sphere of Roman or Greek influence the bishop held the authority; only if in an emergency situation the bishop could not be present, a priest (presbyterus) could be authorised to reconcile a penitent. For the Irish circle of influence any information about the minister of reconciliation is missing. But the Irish penitentials consistently show the good practice that it was the priest's (sacerdos) office to reconcile the penitent. So the assumption appears as obvious that in the Irish influenced area north of the Humber the reconciliation had been entrusted to the priests (sacerdotes).

The different colloquial usage of the Latin words for priest in the different penitence-writings possibly can find the following explanation: the fallen and repentant priest is called presbiter (presbyterus), the priest who receives the confession, measures, and imposes the penance is termed sacerdos. The South-West British Church and in its tradition later the P. Theodori used preferably the Latin term presbyterus, sometimes unsystematically sacerdos. But the Irish Church was aware of a certain distinction: presbyterus marks the ordination's grade, sacerdos a special appointment and commission, here to minister the reconciliation. The notion that in the tradition sacerdos also subsumes the ecclesiastical estate of a bishop seems not to be correct. In the Praefatio Gildae presaged and the so called Synodus I S. Patricii (Bieler 1975: 54) expressively mentioned that no priest should be without a clear appointment to a bishop. So it appears as more likely that the mention of a sacerdos in connection with an episcopus characterized a dependency and an employment relationship: the priest (sacerdos) held a special commission by his bishop (episcopus), for example to minister repentance.

\section{Degree of Penance and Ecclesiastical Estate}

The wide range of regulations, which had been checked against each other (roughly 600 canones), does not make it easy to find consistent degrees of penance running like a thread through the Penitentials. They reach from corrective measures for minor transgressions in a monastic community (for example additional psalm-singing, exclusion from meals, night-watches, 
blows and few days of fasting) to a long or even a lifelong penance for capital (mortal) sins, degradation of clerics into the lay-status or temporary exile. The exclusion from the Church's community was used only as the ultima ratio for those trespassers, who stubbornly persevered in sin or error. In this context however a basic statement is of vital importance, which all Penitentials took for granted and Finnian explicitly stated: there is no sin, which cannot be pardoned by penance as long as one lives. Therefore, a possible reconciliation remained open until the end of life. Despite the bewildering variety at first view a close and detailed comparison reveals two basic lines of penance: three years of fasting for capital (mortal) and a forty-days-penance (quadragesima) or a multiple of this period for minor trespasses.

This specifically applies to the pastoral outside a monastery and extension of regulations to lay-people. A member of a monastic community or of the clergy however had to face a more severe penance in comparison with lay-people (explicitly in Sinodus Luci Victoriae). This regulation too marks a common thread: a religious and an ordained person have to perform a model for a holy life. For this important labour, they can expect a higher reward in the world to come (Paenitentialis Vinniani). But if those ecclesiastical officials commit a capital (mortal) sin or another trespass, they darken the reputation of the Church by establishing a bad example. Therefore, they have to face rigid penances according to the rule: the higher the hierarchical rank the longer the duration of penance.

The overview of the scarlet intercourse of a male and female person and the related penance indeed can serve as an example for the treatment of other capital sins. The basic penance for this sin of fornication (P. Gildae, $S$. Aquilonalis, S. Luci Victoriae, E. Davidis, P. Vinniani, P. Columbani, P. Ambrosianum) actually is three years of fasting by bread and water with some facilitations on Saturday and Sunday. The penance in the Praefatio Gildae, P. Ambrosianum, Cummeani pertains to monks. On condition that this sin was committed by a monk or a member of the clergy, the addition of penance could aggregate for up to ten years (P. Columbani, Ambrosianum, Cummeani: for a bishop). The performance of the penance often could be accompanied by different superpositions: exile, abstinence from meat and wine, harsh sleeping conditions, ban to carry arms, no marital bed, set free a bondsmaid, and compensation in case of begetting a child.

The connection between the archbishop of Greek descent, Theodore of Canterbury, and his predecessor in the bishopric of Caesarea threehundred years before, Basil (1839, Epistola 199), appears in a common regulation: a cleric, who is degraded into the lay-status, is according to the somewhat hedged phrasing in Theodore's penitential (De gradu perdito penitentia mortua est anima vivit, Finsterwalder 1929: 302) not subjected to further penance. The other Penitentials by contrast impose penance as well as 
(in special cases) the loss of a cleric's state (S. Aquilonalis, P. Vinniani, Ambrosianum, Cummeani).

The reconciliation, expressed in the reception of the communion, was only allowed after the fulfillment of the imposed penance (expressively in the $P$. Vinniani). For a monk, it had been certainly burdening, however possible to serve a penance, which lasted years, in his monastery or even in exile. It appeared as more difficult, but not totally impossible for a cleric to atone over a long period under quasi-monastic conditions, because monasteries provided special locations for these penitents.

But for a layperson a nearly insolvable problem arose. A particular statement mentioned in Muratori's penitential-rite (1741: V, 725) put this severe problem in a nutshell: for certain people the fulfillment of a penance's requirements is arduous, if not impossible for those, who had been responsible for a family and relied on labour for mere subsistence. So it is not surprising that within the day-to-day-life of the church ecclesiastical officials were on the lookout for commutations or equivalents, which allowed a layperson to fulfill the requirements of penance on the one hand and to continue the breadwinning on the other hand. A list of these ecclesiastical authorities can be found in the 'Old Irish Table of Commutations' (Bieler 1975: 277-283).

An alteration of penance already was mentioned in the Excerpta Davidis: a three years penance of fasting could be replaced by a certain amount of three-days-periods of fasting. The $P$. Vinniani allowed a penance's limitation by alms for the poor or donations towards ecclesiastical officials (servi Dei). Cummean introduced his penitential with a possible abbreviation by alms and listed various commutations in his penitential. The Discipulus Umbrensium reported that Archbishop Theodore expressed his agreement to alter an imposed penance. A system of commutations or equivalents appears in different writings, called arrea, a latinized term from the vernacular Irish language, which means payment instead of. These arrea had been discussed mainly in the Irish Canones Hibernenses (around 800), Muratori's Ritus poenitentiae (eighth century), the Council of Clovesho (746/747) and the 'Old Irish Table of Commutations' (second half of the eighth century).

The section II of the Canones Hibernenses (Bieler 1975: 163-167) and the Old Irish Table of Commutations are closely related to each other and renounced any pecuniary aspect of commutation. Long prayers and psalmsinging represented the main part of equivalent exercises. But the recitation often had been toughened by a series of escalating tiring and uncomfortable superpositions: little sleep, genuflections, staying in water overnight, sleeping on nutshells or even lying next to a corpse. The commutations also reveal an interesting insight of the human person. Although the wording is targeting superficially-the rescue of the soul-the perspective of these di- 
rections is an integral one, meaning the human person as a whole, with body and soul.

Therefore, the Table of Commutations describes the goal of the arrea as a kind of cure, which combines spiritual exercises and corporal penanceactivities. This fervent praying included tiring chatisement, experiences that cost effort and willpower. The section I of the Canones Hibernenses additionally opened the opportunity to compensate a long-term penance by a pecuniary contribution or an allowance in kind. It represents a disconcerting insight in the contemporary society, which consists of free and unfree people. This becomes obvious, when alongside with the payment of money and the transfer of domestic animals the handover of bond-servants had been a possible commutation. The Ritus poenitentiae (transmitted by Ludovicus Antonius Muratori) reveals another possibility to replace a penance in form of fasting: paying stipends for masses said or even commissioning a monk to serve vicariously the penance.

This favour however included the penitent's obligation to benefit the monastery with a reasonable donation. Especially this option marked a dangerous borderline: such payments and hand-over of goods favoured prosperous people. But the insightful random sample of the Council of Clovesho (Haddan and Stubbs 1964: III, 373, 374) shows an alert awareness of problematic ecclesiastical developments. The Council found itself constrained to argue against the misuse that a penitent could bail out himor herself by paying one or more substitutes.

This alertness allowed the effort of the church's authorities to take up an engaged pastoral responsibility and create for all Christian estates individual solutions to take part in the healing process of repentance. The different options to use the remedy of penance, counselled by spiritual physicians or soul-friends benefited the society, the ecclesiastical and the civil as well. So the Church particularly by the performance of confession in privacy and the imposition of a carefully individualized, but not lax penance bettered the individual person and simultaneously improved justice and righteousness among the community of people living together. It was an essential of all penitence-writings that they aimed at the cure of sinner as an individual and not the mass of human beings in total. The minister of repentance is called to proclaim a releasing message: though the human nature is weak and exposed to temptation there is no reason to despair, because God's mercy is great (P. Vinniani).

In prefaces, prologues, and epilogues the authors of the Penitentials underlined their aim to improve the pastoral abilities of the priests for their ministry of reconciliation. The crucial matter of these authorities always was the improvement of the quality of the personal assistance. They were convinced that the repentant sinner could expect that his or her spiritual at- 
tendant (physician, soul-friend) undertakes his utmost to reconcile him or her to God and the neighbours, the entire healing process of repentance.

As learned and experienced church superiors they realized their pastoral care and responsibility to comply with the request of the ecclesiastical officials, who were entrusted to them and ministered the faithful, but had not available a detailed knowledge of the ministry of repentance. So the Penitentials took on the character of handouts and guidelines to educate and qualify confessors. The priest's (sacerdos) competences exemplarily mentioned in the P. Ambrosianum however allowed an ample scope that could be filled by the minister of repentance playing his role as the penitent's spiritual guide. Because the penitentials aimed at the effort to convert a certain sinner, they nowhere emphasized the quantity of penitents. They rather favoured the quality of the spiritual and pastoral attendance a penitent could enjoy from an attentive and sensitive confessor.

\section{Final Reflections}

Has the form of repentance exercised in the church of today a chance to survive? Especially in the Christian West or ecclesiastical regions of its influence the sacrament of reconciliation remains in a permanent crisis (Coffey 2001: 77, 93-100, 166). The current performance of the sacrament comprehends four different rites. Three forms have sacramental character (first: individual celebration and personal confession, second: communal celebration and personal confession, third: communal celebration and general absolution) and one form represents the non-sacramental penitential service. The comparison of the different forms suggests that the emphasis is on communal components, and that the healing dialogue between penitent and confessor is jeopardized to fall behind in the process of repentance.

As stated above, the spirit of the Penitentials certainly from the P. Vinniani onwards clearly reveals that the entire sense of repentance is not represented by quantity, concluding as many confessions as possible. The emphasis rather is laid on the quality of the process of repentance that includes as a crucial act the healing dialogue between the officiating priest and the repentant person. The minister of repentance, namely, takes the responsibility that the penitent understands a redeeming trias:

- first and foremost, being strengthened in faith that no sin exists, which cannot be forgiven by God's boundless mercy,

- second, being accompanied in the process of repenting by the service of the church, and

- third, declaring oneself willing to fulfill the penance as a remedy to be cured and reconciled with the community of the faithful. 
Like a doctor for the body, who calms a patient after a bad diagnosis with the prospect of a salutary therapy, the spiritual physician is called to offer the person, who is suffering from sin as an ailment of soul, the promising therapy of repentance. So the officiating priest should assist the sinner on his or her way back to a righteous life, but also renew his or her faith in God's boundless love. Being convinced of this redeeming reality the person can experience reconciliation with God, neighbours and-not least-with him- or herself, in order to withstand temptation in the future. Therefore, the role of the minister of repentance is a crucially important one. It appears that the authors actually wanted to do their utmost in intention and performance to fit their entrusted pastors by their Pententials' advice for the demanding service: to turn a comprehensive attention towards people, who ask for repentance.

This process means not less than an extension of friendship: listening to the penitent's personal problems, his or her story of life, burden and wounds he or she has endured, offences committed, his or her weakness, but also abilities, obsessions and honest contrition as well as good will. This is admittedly a process that needs time and claims personal resources. But it nevertheless represents an alternative to penitential-services, where the assembled congregation enters only into a ritualized dialogue, answers preformulated questions and receive a kind of forgiving blessing. In addition, it appears as problematic to require for this blessing the sacramental character of a general absolution, because it converts a regulation for an emergencysituation in a normal practice of the church's day-today life. The question remains, whether this supposed relief meets the necessities of our time.

The possibilities of the internet reveal more and more a lack of consideration, an unscrupulous way of dealing with one another and the absence of healthy relations, respect, sensible attention in personal interaction (Grimm 2008). A willingness to be reconciled can also be absent. Thus, a ceremony of a general forgiveness appears as less helpful for a person, who suffers from being neglected, harmed and caught in personal guilt. A person however can find personal encouragement and the experience of attention in the healing conversation of the Penitentials, which are based on the promise of God's mercy. Reconciled with him- or herself the penitent can advance respect, reconciliation and peace within the society. The engaged authors of the Penitentials taught definitely a pastoral, which centres on the person and prefers a high quality in guiding the faithful on the path of life and to save them from sin, the path of death (Didache 1992: 5, 11). Of course, they also were keen to win as many as possible to believe in practice the faith. But quantity was not their first option. They referred it to the second place. The attraction of the concept of the Penitentials consists in their authors' conviction that winning the entire personality of a human being represents 
the only lasting way to continue to better mankind in the sight of God. Thus the conversion of mankind begins in the conversion of the individuals. This however is a fundamental Christian idea, and the penitentials actually are not far from this notion. The widespread use of the Penitentials until at least $1000 \mathrm{AD}$ proves that their application-though imperfection in some respect-had been not only widely held and successful in the continental and Insular World. They also verify for our time that it is worth to take part in revealing God's redemption, and they can be a means to improve individual and collective integrity in this world: the crucial message of Jesus' proclaiming the Kingdom of God.

\section{Bibliography}

Basil (1839) Basilii Caesareae Capadociae Archiepiscopi Epistolae 188, 199, 217. In Opera omnia, opera et studio Monachorum Ordinis Sancti Benedicti e Congregatione Sancti Mauri, editio Parisina altera, emmendata et aucta, tomus tertius, Parisiis.

Caesarius of Arles (1865) Homilia XIII. In Migne JP (ed) Patrologia Cursus Completus (Series Latina), PL volume 67, Paris.

***** (1975) Canones Hibernenses, II. De arreis (of commutations). In Bieler L (ed/trans) The Irish Penitentials, Scriptores Latini Hiberniae, volume 5. Dublin: The Dublin Institute for advanced Studies.

Cassianus (2004) Collationes. In Petschenig M (ed) Corpus Scriptorum Ecclesiasticorum Latinorum (CSEL), volume 13. Wien: Verlag der Österreichischen Akademie der Wissenschaften.

Coffey DM (2001) The Sacrament of Reconciliation, Lex Orandi series, edited by Laurance JD. Collegeville, MT: Liturgical Press.

***** (1871) Council of Clovesho. In Haddan AW, Stubbs W (eds) Councils and Ecclesiastical Documents relating to Great Britain and Ireland, volume 3, reprint from the first issue 1871. Oxford: The Clarendon Press.

Davies JR (2005) Ecclesiastical Organizations. In Duffy S (ed) Medieval Ireland. An Encyclopedia. New York, NY and London: Taylor and Francis.

***** (1992) Didache. In Lindemann A, Henning P (eds) Griechisch-deutsche Parallelausgabe. Tübingen: Mohr-Siebeck.

***** (1975) Excerpta quaedam de Libro Davidis. In Bieler L (ed/trans) The Irish Penitentials, Scriptores Latini Hiberniae, volume 5. Dublin: The Dublin Institute for advanced Studies.

***** (1997) Sancti Columbani Opera. In Walker GSM (ed/trans) Scriptores Latini Hiberniae, volume 2. Dublin: School of Celtic Studies, Dublin Institute for advanced Studies, reprint from the first issue 1957.

***** (1999) Die Canones Theodori Cantuariensis und ihre Überlieferungsformen. In Finsterwalder PM (ed) Untersuchungen zu den Bußbüchern des 
7., 8. und 9. Jahrhunderts, Band 1. Weimar: Hermann Böhlaus Nachfolger.

Grimm P, Rhein S, Clausen-Muradin E (2008) Gewalt im Web 2.0. Der Umgang Jugendlicher mit gewalthaltigen Inhalten und Cyber-Mobbing sowie die rechtliche Einordnung der Problematik, Schriftenreihe der Niedersächsichen Landesmedienanstalt (NLM), Band 23. Berlin: Vistas Verlag.

Körntgen L (1993) Studien zu den Quellen der frühmittelalterlichen Bußbücher. Sigmaringen: Thorbecke.

***** (1975) Paenitentiale Cummeani. In Bieler L (ed/trans) The Irish Penitentials, Scriptores Latini Hiberniae, volume 5. Dublin: The Dublin Institute for advanced Studies.

***** (1979) The Penitential of Cummean. In McNeill JT, Gamer HM (trans) Medieval Handbooks of Penance. New York, NY: Octagon Books.

***** (1999) Patrick's Address to the soldiers of Coroticus. In O'Loughlin T (ed)

St. Patrick. The Man and His Works. London: Triangle.

***** (1975) Penitentialis Vinniani. In Bieler L (ed/trans) The Irish Penitentials,

Scriptores Latini Hiberniae, volume 5. Dublin: The Dublin Institute for advanced Studies.

***** (1979) The Penitential of Finnian. In McNeill JT, Gamer HM (trans)

Medieval Handbooks of Penance. New York, NY: Octagon Books.

***** (1741) Poenitentiae Ritus e codicibus monastic Monasterii Bobiensis. In Mu-

ratori LA (ed) Antiquitates Italicae medii Aevi, tomus quintus, Milano.

***** (1975) Praefatio Gildae de Poenitentia. In Bieler L (ed/trans) The Irish

Penitentials, Scriptores Latini Hiberniae, volume 5. Dublin: The Dublin Institute for advanced Studies.

***** (1975) Sinodus Aquilonalis Britaniae. In Bieler L (ed/trans) The Irish

Penitentials, Scriptores Latini Hiberniae, volume 5. Dublin: The Dublin Institute for advanced Studies.

***** (1975) Sinodus Luci Victorie, In Bieler L (ed/trans) The Irish Penitentials,

Scriptores Latini Hiberniae, volume 5. Dublin: The Dublin Institute for advanced Studies.

***** (1975) The Old-Irish Table of Commutation. Bieler L (ed/trans) The Irish

Penitentials, Scriptores Latini Hiberniae, volume 5. Dublin: The Dublin Institute for advanced Studies.

***** (1979) An Old Irish Table of Commutations. In McNeill JT, Gamer HM (trans) Medieval Handbooks of Penance. New York, NY: Octagon Books.

***** (1975) Synodus I S. Patricii. In Bieler L (ed/trans) The Irish Penitentials, Scriptores Latini Hiberniae, volume 5. Dublin: The Dublin Institute for advanced Studies.

Theodulfi, Aurelianensis Episcopi (1851) Opera Omnia. In Migne JP (ed) Patrologia Cursus Completus (Series Latina), PL volume 105, Paris.

Tertullian (1869) On repentance. In Roberts A, Donaldson J (eds) Ante-Nicene Christian Library (ANCL), volume 11. Edinburgh: T \& T Clark. 